\title{
Una aproximación al poblamiento de la provincia Guane en las visitas de 1560 y 1572
}

\author{
Artículo recibido: 18-08-2016 / Artículo aceptado: 16-01-2016
}

DOI: $10.25100 /$ hye.v13i49.5854

\begin{abstract}
Álvaro Acevedo Tarazona
Posdoctor en Ciencias de la Educación de la Universidad Pedagógica y Tecnológica de Colombia (UPTC)-Rudecolombia. Doctor en Historia de la Universidad de Huelva, España. Magíster en Historia de la Universidad Industrial de Santander. Magíster en Historia de la Universidad Pablo de Olavide, Sevilla, España. Especialista en Filosofía de la Universidad de Antioquia, Especialista en Docencia Universitaria de la Universidad Industrial de Santander, y Formación Especializada de Docencia en Historia y Cultura de América Latina, Universidad Pablo de Olavide, Sevilla, España. Profesor Titular de la Universidad Industrial de Santander. Director del grupo de investigación Políticas, sociabilidades y representaciones histórico-educativas (Categoría A - Colciencias). Entre sus publicaciones recientes se encuentran los artículos "Ideología revolucionaria y sociabilidad política en los grupos universitarios maoístas de los años 60 y 70 en Colombia”, Historia Caribe XI, 28 (2016): 149-175, y “Escolarización de la enseñanza y formación de maestros. El contexto sociopolítico en la Reforma Instruccionista del Estado Soberano de Santander (1863-1870), preámbulo de las Escuelas Normales en Colombia”, Revista Historia de la Educación Latinoamericana 17, 25 (2015): 51-68. Correo electrónico: tarazona20@gmail.com.
\end{abstract}

\section{Juan Sebastián Bonilla Ayala}

Estudiante del Programa Académico de Historia de la Universidad Industrial de Santander (Bucaramanga, Colombia). Miembro del Semillero de investigación de Hermenéutica Histórica, e integrante del Grupo de Investigación Políticas, sociabilidades y representaciones histórico-educativas (Categoría A - Colciencias). Ha publicado recientemente la reseña del libro "De los conflictos locales a la guerra civil. Tolima a finales del siglo XIX”, Historelo. Revista de historia regional 7, 14 (2015): 303-308. Correo electrónico:_bsebastia98@gmail.com.

Forma de citar este artículo: Tarazona Acevedo, Álvaro y Bonilla Ayala, Juan Sebastián. “Una aproximación al poblamiento de la provincia Guane en las visitas de 1560 y 1572 ". Historia y Espacio, vol. $13, n^{\circ} 49$ (2017): $225-232$.

Artículo Tipo 1: de investigación científica según clasificación de Colciencias. Una versión preliminar de este estudio se presentó durante el Coloquio en Estudios Históricos Regionales (Bucaramanga, Santander, 11 de noviembre de 2015). Este artículo es el resultado de un interés particular de los investigadores. 
Una aproximación al poblamiento de la provincia Guane en las visitas de 1560 y 1572.

Álvaro Acevedo Tarazona

Una aproximación al poblamiento de la provincia guane en las visitas de 1560 y 1572

Resumen: Este artículo indaga sobre la territorialidad y el poblamiento durante la segunda mitad del siglo XVI a partir de las visitas realizadas a la provincia Guane en los años 1560 y 1572. El análisis de las diligencias de visita y de los testimonios de cronistas como Castellanos, Fernández de Oviedo y Fray Pedro Simón, correspondientes a este período, permiten reconocer el entorno territorial de este pueblo a partir de un estudio heurístico. Desde esta mirada analítica, se identificaron algunas pautas de poblamiento de los guanes, el régimen de tributo impuesto en la encomienda a esta población sometida, así como la variedad de productos que intercambiaban con poblaciones vecinas. Asimismo, a través de estas diligencias de visita se pueden establecen patrones de comportamiento en cuanto al régimen alimenticio, vestuario y costumbres del grupo guane, después de su contacto con los conquistadores españoles.

Palabras clave: departamento de Santander, etnia, poblamiento, provincia Guane, territorio, intercambio.

\section{An Approach to Settlement of the Province Guane Visits in 1560 and 1572}

Summary: As the Guanes the largest indigenous group that inhabited the present department of Santander, the article explores the territoriality and settlement during the second half of the sixteenth century from visits to the Guane Province in the years 1560 and 1572. The analysis of measures of visit for the years 1560 and 1572 as well as the testimonies of chroniclers as Castellanos, Fernández de Oviedo and Fray Pedro Simon can recognize the territorial environment of this town from a heuristic study to the scarce literature for the subject. From this perspective, some analytical habitation patterns of Guanes, the tax regime on the parcel tribute to this subject population, and the range of products traded with neighboring populations were identified. The traumatic subjugation of this people coupled with epidemics and rapid mixing does not reveal in depth aspects of this ethnic group, including items such as its economy, its habitat and its forms of organization.

Keywords: Department of Santander, Ethnicity, Population, Province Guane, Territory

\section{Uma abordagem para liquidação das visitas província Guane in 1560 and 1572}

Resumo: Como os Guanes o maior grupo indígena que habitava o actual departamento de Santander, o artigo explora a territorialidade e liquidação durante a segunda metade do século XVI de visitas à Província Guane nos anos 1560 e 1572. A análise das medidas de visita para os anos de 1560 e 1572, bem como os testemunhos de cronistas como Castellanos, Fernández de Oviedo e Fray Pedro Simon pode reconhecer o ambiente territorial desta cidade a partir de um estudo de heurística para a escassa literatura para o sujeito. A partir desta perspectiva, algumas diretrizes povoamento analítica dos Guanes, o regime 
fiscal sobre o tributo pacote para esta população assunto, ea gama de produtos comercializados com as populações vizinhas foram identificados. A subjugação traumática deste povo juntamente com epidemias e mistura rápida não revela em aspectos profundidade deste grupo étnico, incluindo itens como a sua economia, o seu habitat e as suas formas de organização.

Palavras-chave: Departamento de Santander, Etnia, Poblamiento, Província de Guane, Território 
Una aproximación al poblamiento de la provincia Guane en las visitas de 1560 y 1572.

Álvaro Acevedo Tarazona - Juan Sebastián Bonilla Ayala

\author{
Álvaro Acevedo Tarazona \\ Juan Sebastián Bonilla Ayala \\ Una aproximación al poblamiento \\ de la provincia Guane en las visitas \\ de 1560 y 1572
}

\title{
Introducción
}

Los estudios existentes sobre los guanes son escasos si se tiene en cuenta el número de investigaciones realizadas sobre otras sociedades originarias del actual territorio colombiano. La mayor parte de estos trabajos se han enfocado en el análisis de artefactos, cerámicas, textiles, pictogramas y restos óseos que se han hallado en sitios arqueológicos ubicados en el departamento de Santander ${ }^{1}$. Lamentablemente, algunos aspectos como la economía de este grupo han sido poco tratados y las referencias en cuanto al intercambio de objetos con sus vecinos son bastante escasas.

1 Justus Schottelius, Arqueología de la Mesa de Los Santos (Bogotá: Educación, 1941), Edith Jiménez, "Colecciones del Museo Nacional de Arqueología: una colección de cerámica guane”, Boletín de Arqueología, II, 5-6 (1945): 413-421, Martín Carvajal, "Recuerdos arqueológicos de Santander”, Estudio 104-107 (1941); Donald Sutherland, Investigaciones preliminares sobre la prehistoria de Santander (Bucaramanga: Universidad Industrial de Santander, 1990); Arturo Vargas y Roberto Lleras, "Palogordo. La prehistoria de Santander en los Andes Orientales", Boletín Museo del Oro 26 (1990): 64-129; Marianne Cardale de Schrimpff, El arte del tejido en el país guane (Bucaramanga: Banco de la República, 1993), Arturo Cifuentes, "Reseña de un sitio arqueológico en la Mesa de Los Santos (Santander)”, Boletín de Arqueología, 2 (1989): 33-40; Leonardo Moreno, "Arqueología del nororiente colombiano. Los Teres: un sitio de asentamiento de las culturas prehispánicas preguane y guane”, Anuario de Historia Regional $y$ de las Fronteras 17, 2 (2012): 115-142; Leonardo Moreno, "Los Teres: un asentamiento ordenador del territorio preguane-guane. Una aproximación al tema urbano", Anuario de Historia Regional y de las Fronteras 18, 2 (2013): 521-548. 
Carl Henrik Langebaek, en sus libros Noticias de caciques muy mayores ${ }^{2}$ y Mercados, poblamiento e integración étnica entre los muiscas ${ }^{3}$, menciona la existencia de intercambios de artículos y alimentos entre guanes y muiscas mediante la participación en visitas y en mercados periféricos (Sorocotá). Del mismo modo, Jorge Morales y Gilberto Cadavid indican que "el comercio parece haber sido muy activo entre los guane" y que en el Río del Oro se practicaban intercambios con yariguíes y chitareros ${ }^{4}$.

En referencia a las fuentes primarias que se utilizaron para la construcción de este escrito debe decirse que estas no son generosas en información acerca del tema. Los datos obtenidos se tomaron de las crónicas y las visitas a Santander realizadas durante el siglo XVI (1560 y 1572) a los repartimientos de la provincia Guane. Hay que advertir que estas últimas deben ser tomadas con precaución, sobre todo en lo que respecta a datos demográficos, debido a que cuando tenía lugar ese tipo de diligencias, los caciques procuraban esconder el número real de aborígenes que habitaban sus pueblos con el fin de disminuir el monto de la tributación.

Los grupos aborígenes que habitaron la provincia Guane durante el siglo XVI cultivaron diversos granos y frutos mediante el uso de diferentes técnicas agrícolas con el fin de explotar mejor los recursos naturales existentes en la zona. Si bien las cosechas representaron su mayor sustento, lo producido no satisfacía totalmente las necesidades de la población. La necesidad de complementar una dieta dio paso a un permanente contacto entre los guanes y otras sociedades para proveerse mediante el intercambio de recursos alimenticios y productos en general. Es importante aclarar que al hacer mención de las necesidades de la población, a propósito del intercambio, no se alude solo a aspectos relacionados con su nivel nutricional, sino también a otros productos necesarios para sus actividades económicas y culturales.

Además, se deben tener en cuenta dos características únicas de esta población, a saber, su rápida extinción como resultado en parte del temprano mestizaje con los conquistadores españoles, y como consecuencia de su

2 Carl Henrik Langebaek Rueda, Noticias de caciques muy mayores (Bogotá: Universidad de los Andes-Universidad de Antioquia, 1992).

3 Carl Henrik Langebaek Rueda, Mercados, poblamiento e integración étnica entre los muiscas. (Bogotá: Banco de la República, 1987).

4 Jorge Morales Gómez y Gilberto Cadavid Camargo. Investigaciones arqueológicas y etnohistóricas en el área guane (Bogotá: Fian, 1984). 
Una aproximación al poblamiento de la provincia Guane en las visitas de 1560 y 1572.

Álvaro Acevedo Tarazona - Juan Sebastián Bonilla Ayala

aislamiento geográfico ${ }^{5}$. A esta situación habría que sumarle las confrontaciones con los conquistadores, la mita y las enfermedades, que disminuirían considerablemente la población ${ }^{6}$. La segunda característica tiene que ver con los rasgos corporales de esta población, derivados de estudios escanográficos y radiográficos realizados por arqueólogos a momias guanes encontradas en la Mesa de Los Santos. Estos trabajos han refirmado la idea de que los guanes tenían un "aspecto caucasoide", sin ser necesariamente "blancos" como han sostenido otras investigaciones ${ }^{7}$.

Indagar el tipo de relaciones de intercambio que establecieron los indígenas de la provincia Guane ${ }^{8}$ con otros grupos vecinos durante el siglo XVI continúa siendo de suma importancia para comprender al grupo aborigen más importante del actual departamento de Santander, ubicado principalmente en la Mesa de Xerira (Mesa de Los Santos). Para ello se propone en este artículo, en primera instancia, reconocer el territorio habitado por los guanes; en segundo lugar, hacer algunas breves referencias en cuanto a su población para el siglo XVI y los tipos de asentamientos donde se ubicaban y, finalmente, abordar algunos aspectos relacionados con su producción económica.

5 José Vicente Rodríguez C., "Características físicas de la población prehispánica de la cordillera Oriental: implicaciones etnogenéticas”, Maguare, 8 (1992): 18.

6 Amado Antonio Guerrero Rincón y Armando Martínez Garnica, La provincia de Guanentá. Orígenes de sus poblamientos urbanos (Bucaramanga: Ediciones UIS, 1996), 29.

7 Los investigadores Alejandro Navas Corona y Martín David Acevedo reconstruyeron el rostro de un guerrero guane recurriendo a la craneometría forense y a la investigación de campo forense. El estudio señala que los guanes tenían una deformación dolicocéfala, al parecer proveniente de la idea de que su rostro tomaba la apariencia de un felino, por lo que tenían una apariencia que los diferenciaba de otras etnias como los muiscas, yariguíes, chitareros, entre otros. Martín David Acevedo y Alejandro Navas Corona, Entre rostros y tumbas (Bucaramanga: Sic, 2010).

8 En la historiografía se identifica pueblo guane, provincia guane o territorio guane. Si bien cada autor ha establecido parámetros de delimitación geográfica, es evidente que no existe una claridad sobre si era un grupo estructurado como el muisca. No obstante, los cronistas se refieren a la provincia de guane, pero no corresponde al territorio guane existente antes de la Conquista. Además, aún no existe la suficiente información arqueológica para dicha reconstrucción. Sin |embargo, las excavaciones arqueológicas realizadas por el profesor Leonardo Moreno dan cuenta de que el territorio guane era más extenso que lo que proponen los cronistas (Diana Ardila, "Configuración de paisajes coloniales en el territorio guane, Santander (Colombia)" (tesis Magíster en Medio Ambiente y Desarrollo, Universidad Nacional de Colombia, 2010). 


\section{Territorio: la respuesta guane al paisaje}

El territorio puede entenderse como el "espacio apropiado por un grupo social para asegurar su reproducción y la satisfacción de sus necesidades vitales, que pueden ser materiales o simbólicas"9. En el caso del grupo guane, este habitó parte de lo que hoy se conoce como el departamento de Santander, localizado en la zona nororiental de los Andes colombianos. Las crónicas ayudan a esclarecer e identificar el territorio guane como se puede evidenciar en Elegías de varones ilustres de Indias:

(...) hacia la parte del Oriente viva peña tajada la rodea, a quien llamamos cingla comúnmente, que corre Norte Sur algo torcida más espacio que dura la provincia; pero por la frontera de los Guanes y corre furioso por sus tierras, donde se junta con de Suárez y otro que Chalala tiene por nombre. Cuyas corrientes van encaminadas al río Grande de la Magdalena, de suerte que por debajo de la cingla sabanas razas hay, pero desiertas, excepto la que tienen más a mano que llamamos la Mesa de Xerira ${ }^{10}$.

En cuanto a la ubicación de la provincia, Fernández de Piedrahíta hizo la misma observación que Castellanos y agregó que "por la parte baja de la Singla al Ocaso tienen su asiento los Guanes, y en lo alto de la peña hay campañas rasas, excepto la más cercana, que llaman la mesa de Jerirá, que sola ella tendrá de circunvalación veinte millas de tierras limpias, fértiles, llanas y apacibles (...) Confinan con esta provincia las arenas del Río del Oro" ${ }^{11}$. Por su parte, Fray Pedro Simón escribió que "no tanto llegan sus términos por la parte del Norte al Río del Oro...aunque reduciendo sus términos a esta provincia, sólo se extiende por allí al río Sogamoso"12.

Las descripciones limítrofes sobre esta etnia realizadas por los cronistas Castellanos, Piedrahíta y Simón sirvieron de base a los estudios realizados por Morales y Cadavid para entender la extensión y límites que alcanzó este

9 Gilberto Jiménez, “Cultura, territorio y migraciones. Aproximaciones teóricas”, Alteridades 11, 22 (2001): 6 .

${ }^{10}$ Juan de Castellanos, Elegías de varones ilustres de Indias (Bogotá: Biblioteca de la Presidencia de la República, 1955), 252.

${ }^{11}$ Lucas Fernández de Piedrahíta, Historia general de las conquistas del Nuevo Reino de Granada (Bogotá: Imprenta de Medardo Rivas, 1881), 252.

${ }^{12}$ Fray Pedro Simón, Noticias historiales de la conquista de tierra firme en las Indias Occidentales por Fr.Pedro Simón del orden de San Francisco del Nuevo Reino de Granada (Bogotá: Casa Editorial de Medardo Rivas, 1881), tomo IV. 
Una aproximación al poblamiento de la provincia Guane en las visitas de 1560 y 1572.

Álvaro Acevedo Tarazona - Juan Sebastián Bonilla Ayala

territorio. Es importante mencionar que exceptuando a Piedrahíta, las crónicas no mencionan el río del Oro como límite norte de las tierras de los guanes, pero estos dos autores decidieron tomarlo en cuenta a partir del hallazgo de un documento fechado en 1561 en el cual se interrogaba a un vecino de Vélez sobre el tratamiento recibido por las cuadrillas de indígenas que trabajaban en dicho río:

(...) dijo el testigo ha estado en el Río de Oro algunas veces e ha visto indios Guanes de Bartolomé González y Francisco Ruiz y Francisco de Murcia y Francisco Franco y de Juan Quintero y de Alonso Domínguez y de Gil Moreno y el menor de Gonzalo de Vega...y de la viuda de Pedro Gutiérrez y de Pedro de la Cuesta y de Lorenzo Benítez y de Bartolomé Hernández Cepeda vecinos desta ciudad a sacar oro en las minas del Rio del Oro y no en el de Suratá y que el Rio del Oro es en tierras de Guane es toda una de una temple e no lejos de sus casas $(\ldots)^{13}$.

De esta manera, Morales y Cadavid concluyeron que el área ocupada por los guanes para la época de la Conquista se extendía -en términos actuales- por el oriente, hasta el ramal de la cordillera Oriental formado por los páramos de La Rusia, Guantiva y Barrosa; por el norte, el punto más septentrional lo conformaban la unión del río Suratá con el río del Oro hacia el sur hasta encontrar el río Chicamocha en la boca del Umpalá y de allí hasta la población de Cepitá comprendiendo las extensiones de la Mesa de Los Santos y la meseta de Bucaramanga; por el occidente, de Güepsa al norte por la banda del río Suárez hasta encontrar la hoya del Río del Oro al occidente de Bucaramanga; y por el sur, siguiendo los cursos de los ríos Tolotá y Lenguaruco ${ }^{14}$. Lo cierto es que la extensión del límite norte de los guanes hasta el río del Oro es poco probable, en primer lugar, porque no se han encontrado evidencias arqueológicas que sustenten este límite; en segundo lugar, porque las cuadrillas de población guane encontradas como referencia en el río del Oro son de fechas posteriores a la Conquista, cuando ya se extraía oro de aluvión de este sitio haciendo parte de un proceso productivo implementado por los ibéricos.

${ }^{13}$ Morales y Cadavid, Investigaciones etnohistóricas, 19.

${ }^{14} \mathrm{Al}$ respecto, cabe anotar la controversia sobre si las actuales poblaciones de Guaca y San Andrés pertenecían al territorio de los guanes. Lo más probable, según los trabajos de Jorge Morales, es que se tratase de otros grupos confundidos con la tradición guane. Jorge Morales, "Tejedores indígenas en la montaña santandereana", Boletín de Historia y Antigüedades XCIII, 831 (2005): 745-768. 


\section{Mapa 1. Ubicación del territorio guane en Colombia}

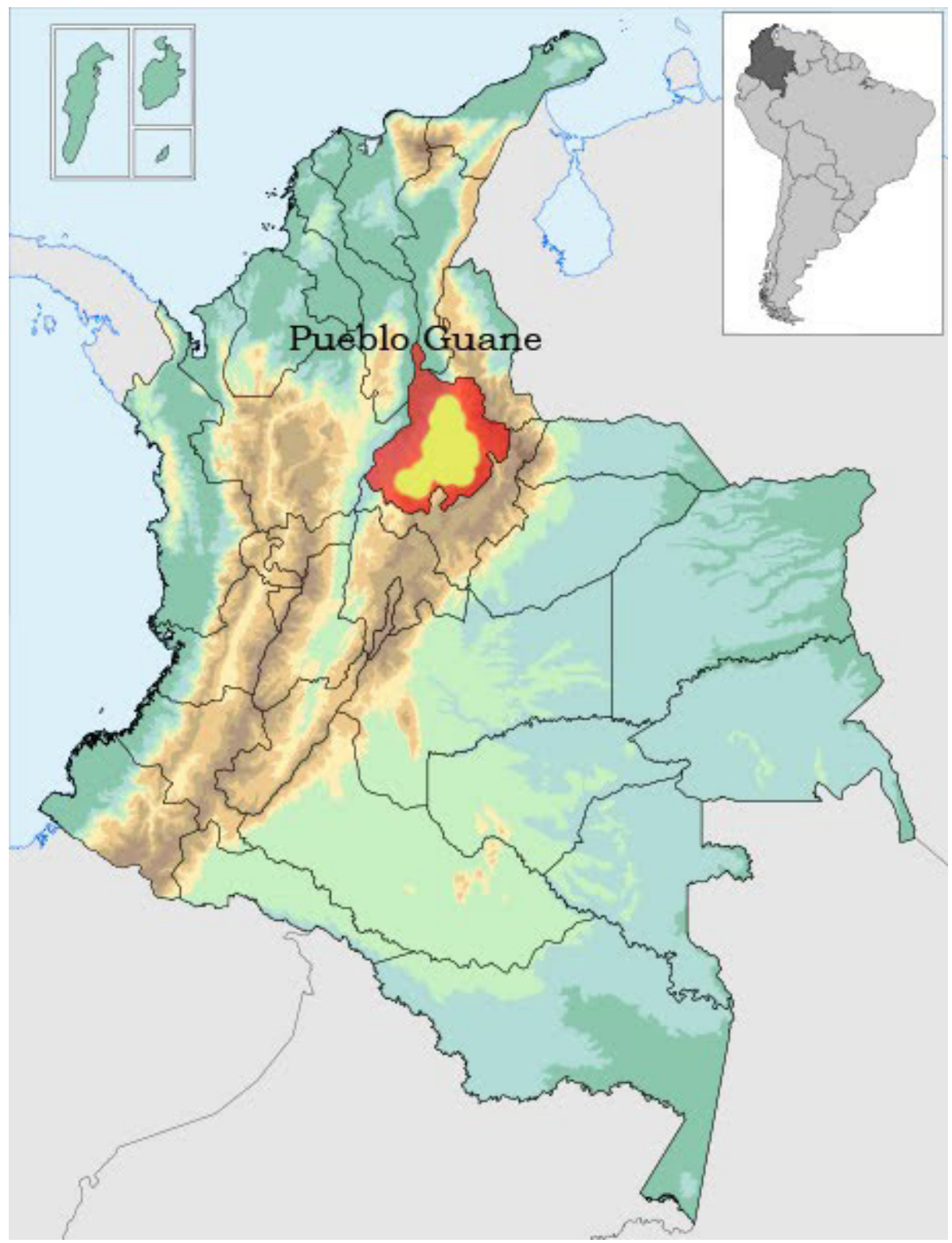

Fuente: Alirio Gómez Martínez, El guane, (Floridablanca: 2011), consultado 18/01/2017,. http://elguane.blogspot.com.co/ 
Una aproximación al poblamiento de la provincia Guane en las visitas de 1560 y 1572.

Álvaro Acevedo Tarazona - Juan Sebastián Bonilla Ayala

\section{Mapa 2. Área del territorio guane}

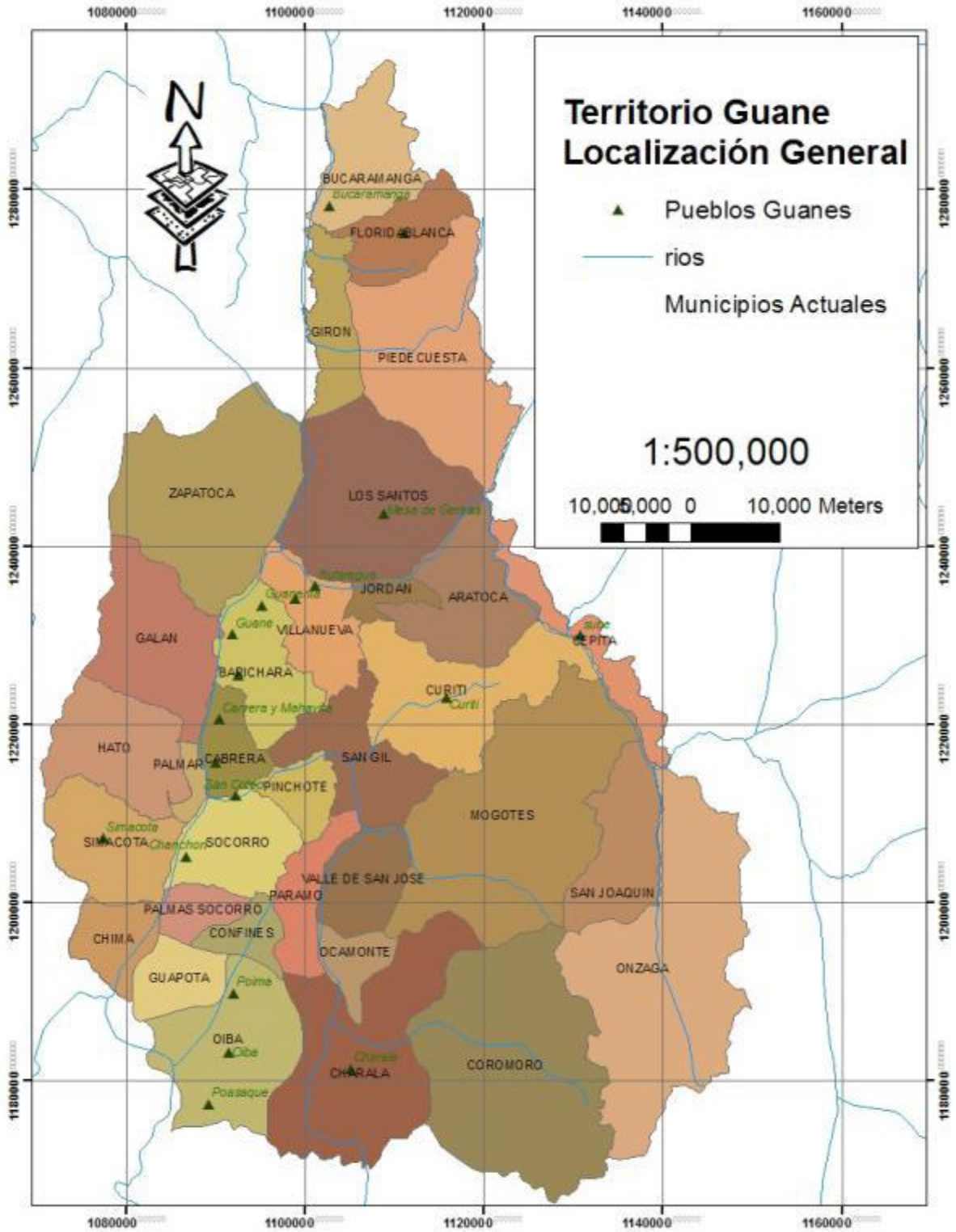

Fuente: Diana Ardila Luna, "Configuración de paisajes coloniales en el territorio guane, Santander (Colombia)", (Tesis de Maestría en Medio Ambiente y Desarrollo, Universidad Nacional de Colombia, 2010), 14. 
En sus escritos los cronistas mencionaron las posibilidades habitables de este lugar y lo describieron como una tierra "pedregosa, seca y de buen temple, más caliente que fría, de buenos y saludables aires por ser limpia de montañas y anegadizos"15 para la crianza de ganado y el cultivo de toda clase de granos $\mathrm{y}$ frutas.

El territorio de los guanes también se caracterizó por poseer una gran variedad de ecosistemas. Siguiendo el trabajo de Ardila Luna ${ }^{16}$, la autora divide el área en cuatro "zonas de vida” que pudieron ser aprovechadas por los guanes para la obtención de diversos recursos. La primera de estas zonas correspondía a donde hoy se ubican los municipios de Cabrera, Barichara, Guane, Villanueva, San Gil, Pinchote y Los Santos, donde existía una vegetación de bosque seco tropical determinada por el empobrecimiento de la vegetación debido a las temporadas de sequía; y de bosque seco premontano, entre 800 y 1.400 metros de altura, definida por una precipitación aún más baja si se tiene en cuenta la temperatura entre 18 y 24 grados centígrados. La segunda zona comprendía los ríos Suárez, Chicamocha, Fonce y la Mesa de Los Santos, poblada por bosques de tipo muy seco tropical y monte espinoso premontano; predominaba una vegetación xerofítica, árboles de cinco metros de altura y poca lluvia. Una tercera zona la formaban los actuales municipios de Aratoca, Curití, Socorro y Zapatoca, destacándose la presencia de bosque húmedo premontano, lo que contribuía a la existencia de suelos mucho más fértiles. Finalmente, una cuarta zona de bosque húmedo montano y bosque húmedo premontano situada en los actuales municipios de Oiba, Mogotes, Charalá y Ocamonte, con temperaturas medias anuales entre 18 y 24 grados centígrados y precipitación media anual entre 2.000 y 4.000 milímetros.

No obstante esta descripción del territorio ocupado por los guanes, es relevante considerar que el paisaje se constituye en otra categoría importante para la interacción de un grupo humano con un territorio. El paisaje se puede considerar "como una suma de 'espacios naturales y sociales' que relaciona el

${ }^{15}$ Fray Pedro Simón, Noticias historiales, 25. Sobre la ausencia de montañas que menciona Simón, Morales y Cadavid (p. 28) explican que "no se refiere a accidentes topográficos pues es evidente que las hoyas de los ríos Suárez y Chicamocha son muy agrestes y de relieves sumamente montañosos, sino a áreas selvosas y malsanas a los ojos de los españoles que comparaban tal hábitat con tierras como la sierra del Opón”.

${ }^{16}$ La autora advierte que según el Consejo Regional de Planificación (Corpes), los ecosistemas de esta región de Santander han sido altamente trasformados por actividades antrópicas por lo que no se conservan bosques naturales. La descripción de los bosques es una retrospectiva de lo que pudo haber sido en condiciones de menor impacto del ser humano. 
Una aproximación al poblamiento de la provincia Guane en las visitas de 1560 y 1572.

Álvaro Acevedo Tarazona - Juan Sebastián Bonilla Ayala

ámbito de lo objetivo-material con lo ambiental y cultural"17 porque el concepto de paisaje no se puede desligar de la complejidad que le han otorgado varias disciplinas como la historia, la geografía, la arqueología y la antropología porque el paisaje no puede estar desprendido de su contenido visible (geografía), de sus contrastes regionales (antropología), de sus patrones de colonización (historia) a más de las trasformaciones que sufre debido a otros factores: "el estudio del paisaje nos enfrenta con tres cuestiones fundamentales: el papel del tiempo, las limitaciones de lo visible, y la complejidad de los fenómenos que lo componen. El paisaje no es resultado de una generación espontánea, ni siquiera sólo de un proceso evolutivo, por tanto, estudiar el paisaje sin retroceder a sus antecedentes es condenar el estudio a lo inmediato coartando su real comprensión"18. Así, la geografía tiene "la labor de señalar y relacionar las fuerzas sociales, políticas y culturales que han estructurado aquellos mapas culturales con los que representamos el mundo" ${ }^{19}$. Es decir, si bien la geografía es el punto analítico de partida para explicar cómo un grupo humano establece su territorialidad, no se debe desconocer que es un proceso en doble sentido: el humano conquista el terreno y el terreno conquista al grupo humano a través de los lazos ambientales y culturales que se establecen dentro de la comunidad como resultado de la interacción con el paisaje social y natural.

Si se siguen las pautas de poblamiento de los guanes descritas por el profesor Leonardo Moreno, se descubre que la geografía ayuda a comprender los fenómenos sociales vividos por este grupo humano. Sus recientes excavaciones arqueológicas demuestran dinámicas sociales y de poblamiento inscritas en procesos etnosociales amplios y antiguos ${ }^{20}$. La cultura material y la alfarería encontradas en sus excavaciones demuestran que el territorio guane se expandió en amplios terrenos del oriente colombiano en búsqueda de nuevas y enriquecedoras dinámicas sociales y de poblamiento. Los contactos no fueron solamente con los muiscas; hay evidencias de contacto con grupos como los chitareros, laches y yareguíes y se infiere por los rastros arqueológicos (cerámica) que su influencia llegó hasta las fronteras con el actual territorio

\footnotetext{
${ }^{17}$ Moreno, "Arqueología del nororiente colombiano", 121.

${ }^{18}$ Camilo Contreras Delgado, "Pensar el paisaje. Explorando un concepto geográfico", Trayectorias, vol. VII, n. ${ }^{\circ} 17$ (2005), 61.

${ }^{19}$ Sarah de Mojica, Mapas culturales para América Latina. Culturas híbridas, no simultaneidad, modernidad periférica (Bogotá: Pontificia Universidad Javeriana, 2001), 4.

${ }^{20}$ Moreno, "Arqueología del nororiente colombiano", 139.
} 
venezolano ${ }^{21}$. Asimismo, el territorio de los guanes fue campo de intercambio económico y de integración social, pero por algunos vestigios encontrados también se evidencia que fue escenario de guerra con otros grupos. De igual forma, investigadores como Schotelius, Southerland, Lleras, Vargas, Cadavid y Morales han dejado planteada esta opción y han propiciado estudios en la zona con el fin de encontrar nuevas pistas sobre la cotidianidad del grupo guane que explique lo que arqueológicamente se ha denominado como "estilo guane".

Los mismos vestigios culturales tales como sitios de vivienda y tumbas son testimonios sincrónicos de ese periodo, lo cual restaría "importancia a las explicaciones por asociación o difusión de la cultura material, que ha llevado a equiparar a la sociedad guane como un apéndice de la sociedad muisca"22. No en vano los conquistadores en el siglo XVI hablan de "nación guane" como un grupo prehispánico identificado étnicamente con una consolidación social y cultural. Estos vestigios materiales del pasado dan respuesta acerca de la actividad social y la vida cotidiana de los guanes. Por tanto, no hay que olvidar que "el asentamiento prehispánico, es un espacio en donde se desarrolló también la vida social humana y en donde se expresa toda su representación material y social, incluyendo el ámbito de la cultura”23. Es decir, los asentamientos humanos son espacios físicos y sociales en un territorio, lo cual permite argumentar que en la explicación de un grupo social prima la interacción humana y no propiamente lo referente al espacio limítrofe territorial. Empero, el punto de partida para reconocer a un grupo humano se expresa físicamente como un lugar o territorio:

Bajo esta perspectiva, el asentamiento es un soporte físico, pero, a la vez, es una unidad social que inserta numerosas actividades configurando la vida social humana en comunidad, conectando los sujetos sociales y su representación material en este espacio físico aprehendido socialmente, como escenario compartido por los pobladores de manera dialéctica en función de necesidades e intereses, conformando un tejido social y un universo mágico, ritual y simbólico -también materializado en la arquitectura- que

${ }^{21}$ Rodríguez C., "Características físicas de la población”, 13, 26. Este autor hace énfasis en el contacto de los guanes con algunos grupos ubicados en el actual territorio de Norte de Santander y un poco más allá de la frontera venezolana a partir del análisis de las series craneales y de algunos artefactos cerámicos encontrados en sitios como la Serranía de Perijá y La Pica, estado Aragua, Venezuela.

22 Moreno, "Arqueología del nororiente colombiano", 139.

${ }^{23}$ Moreno, "Los Teres: un asentamiento ordenador", 525. 
Una aproximación al poblamiento de la provincia Guane en las visitas de 1560 y 1572.

Álvaro Acevedo Tarazona - Juan Sebastián Bonilla Ayala

conforma ese sentido de vecindad, reconocimiento cultural y de identidad a partir del asentamiento ${ }^{24}$.

Es decir, las pautas de asentamiento son respuestas humanas de carácter histórico referidas al ámbito económico, social, político y cultural que un grupo realiza ante las necesidades de supervivencia material dentro de un territorio determinado. Estas necesidades son identificables en los arreglos espaciales realizados al territorio (vivienda, formas de ocupación, arquitectura) y en la actividad cotidiana (organización social, intercambios económicos, prácticas religiosas, ideología) que también son evidenciadas en los registros arqueológicos y en la trasformación misma del paisaje ocupado por una población. De manera que el poblamiento y la demografía de los guanes se constituyen en variables necesarias para entender su economía y la importancia del intercambio de productos con otros grupos indígenas.

\section{Población: el control español a la organización guane}

Según las descripciones de los cronistas, a la llegada de las huestes de Martín Galeano $^{25}$ en el siglo XVI, el territorio guane se hallaba bastante poblado y se podían observar grandes pueblos apartados unos de otros en donde se alcanzaban a contar unas treinta mil casas habitadas por dos o tres indígenas cada una ${ }^{26}$. De lo expresado podría inferirse una población entre los ochenta mil o noventa mil indígenas, aproximadamente. Cifra que de todos modos no

\footnotetext{
${ }^{24}$ Ibíd., 525.

${ }^{25}$ Martín Galeano fue un conquistador español que llegó a América en la expedición de Pedro Fernández de Lugo junto a la hueste de Gonzalo Jiménez de Quesada. Se destacó por ser el fundador de la ciudad de Vélez y encomendero de un amplio territorio desde Chiquinquirá hasta Vélez. Por encargo de Jiménez de Quesada, fundó la ciudad de Vélez, el 3 de junio de 1539, con el objetivo de controlar el tráfico de pasajeros y mercancías que penetraran al Nuevo Reino por la vía del río Opón desde la ciudad de Santa Marta. Galeano se convirtió en un próspero mercader, no obstante, en varios procesos efectuados por Antonio de Luján, Alonso de Zorita y Andrés Martínez de Casanova, fiscales y defensores de los indios, se comprobó la crueldad aplicada por Galeano hacia los indios de sus encomiendas de Chanchón, Chipatá, Saboyá, Guavatá, Semiza y Agatá, lo cual le acarreó el destierro del Nuevo Reino por dos años. Finalmente, falleció en la embarcación "La Gallega" en 1554 cuando viajaba de Cartagena a España a pagar su condena. Armando Martínez Garnica, La provincia de Vélez. Orígenes de sus poblamientos urbanos (Bucaramanga: Ediciones UIS, 1997), 186-187.

${ }^{26}$ Morales y Cadavid, Investigaciones arqueológicas, 41.
} 
deja de ser muy alta. De igual modo, se podría pensar en la existencia de un patrón de poblamiento nucleado y disperso.

La transición entre el ordenamiento territorial prehispánico y el colonial aún no ha sido estudiada para el caso de los guanes por lo que no se tiene conocimiento si este se mantuvo o fue modificado por los españoles durante el siglo XVI. Es probable que para estos primeros años no se hubiesen presentado serias variaciones y se conservara aquel tipo de poblamiento nucleado y disperso característico de la época prehispánica; sin embargo, no se puede decir lo mismo para los siglos siguientes. Este tipo de ordenamiento distaba mucho de los requerimientos organizativos que la legislación indiana buscaba imponer a los grupos aborígenes hacia finales del siglo XVI: congregación en pueblos construidos a semejanza de los españoles, es decir, en torno a la iglesia ${ }^{27}$. A esta región se le denominó con el nombre de provincia Guane ${ }^{28}$ y fue incorporada a la jurisdicción del cabildo de Vélez ${ }^{29}$, compuesta por los pueblos de Ciribiti, Guanentá, Butaregua, Chocoa, Zapamanga, Jérira, Choaguete, Mahavita, Macaregua, Moncorá, Calvera, Sube, Siscota, Carahota, Cuyamita, Oiba, Lenguaruco, Chalala, Singuanchón, Poasaque, Sancoteo, Corata, Lubegara, Oroco y Burereque, cuyos pobladores, una vez sometidos, fueron repartidos en encomiendas a soldados que habían participado en expediciones y descubrimientos de tierras en el Nuevo Reino de Granada ${ }^{30}$ : “(...) y porque es justo que a los que sirven a su magestad sean remunerados de sus servicios encomiendo en vos en términos de la dicha çibdad de Vélez dos pueblos de yndios llamados Vagachica y Mirava y en la Provinçia de Guane otros dos prinçipales llamados Oro y Burereque (...)”. Para facilitar el régimen de encomienda, los caciques y capitanes guanes fueron mantenidos en sus cargos y dispuestos para organizar a los pobladores aborígenes para acudir al

${ }^{27}$ Martha Herrera Ángel, Poder local, población y ordenamiento territorial en la Nueva Granadasiglo XVIII (Bogotá: Archivo General de la Nación, 1996), 52-53.

${ }^{28}$ De acuerdo con Martha Herrera Ángel el concepto de provincia se utilizó en el siglo XVI para referirse a "unidades administrativas mayores y también a sus subdivisiones". Martha Herrera Ángel, Ordenar para controlar. Ordenamiento espacial y control político en las llanuras del Caribe y en los Andescentralesneogranadinos. Siglo XVIII (Medellín: La Carreta-Universidad de los Andes-Ceso-Instituto Colombiano de Antropología e Historia, 2007), 132,

${ }^{29}$ Guerrero y Martínez, La provincia de Guanentá, 22.

${ }^{30}$ José María Ots Capdequí, España en América. Las instituciones coloniales (Bogotá: Universidad Nacional de Colombia, 1992), 73. 
Una aproximación al poblamiento de la provincia Guane en las visitas de 1560 y 1572.

Álvaro Acevedo Tarazona - Juan Sebastián Bonilla Ayala

trabajo, dirigir las tareas y trasmitir las demandas de sus nuevos amos ${ }^{31}$. Esto se puede apreciar en las diversas actividades económicas que empezaron a desarrollarse en la región, sobre todo en el trabajo de las cuadrillas de indios lavadores asentadas en el río del Oro, en aquellas labores destinadas a la siembra y recolección de maíz, el tejido de mantas de algodón y la confección de alpargates para pagar el tributo a sus encomenderos.

Los documentos surgidos de las visitas ${ }^{32}$ realizadas a las encomiendas de la provincia Guane en 1560 y 1572 contienen los datos entregados por los caciques en el interrogatorio para averiguar por el número de nativos en sus pueblos y, en ocasiones, las listas que elaboraba el visitador para corroborar dicha información. De estos dos procesos resultaron cifras que contenían el número de hombres casados, solteros, huidos, menores y muchachos -entre los seis y los diez años de $e^{2} \mathrm{~d}^{33}$-, aunque los dos últimos ítems son bastante

${ }^{31}$ Según Jorge Gamboa, los caciques y capitanes "fueron mantenidos en sus cargos después de la conquista por simple pragmatismo, pero también porque existía una política general de la Corona española para respetar a las autoridades indígenas americanas, dadas las ventajas que esto suponía para la administración colonial" (Jorge Gamboa, "Las instituciones indígenas de gobierno en los años posteriores a la conquista: caciques y capitanes muiscas del Nuevo Reino de Granada (1537-1650)", en ed. Manolo Florentino y Carlos Eduardo Valencia Villa, Imperios ibéricos en comarcas americanas: estudios regionales de historia colonial brasilera y neogranadina (Bogotá: Universidad Federal do Rio de Janeiro-Universidad del Rosario, 2008), 13.

${ }^{32}$ Las visitas efectuadas a las encomiendas del Nuevo Reino eran realizadas por los escribanos de visitas y el documento resultado de dichas visitas (diligencia de visita) consignaba datos numéricos de la cantidad de indígenas tributarios adscritos a una encomienda. De igual forma, en dicho documento también se registraba el lugar de la encomienda, el nombre de su encomendero y la tasación de los tributos que debían cancelar pues la encomienda fue una institución que consistía en la entrega de tierras e indígenas que vivían en ellas a los conquistadores, en mérito por sus servicios a la Corona. Aaron Copland, Historia de la estadística en Colombia (Bogotá: Dane, 1978). Asimismo, las crónicas de Indias, entre ellas, las de autores como Juan de Castellanos, Gonzalo Fernández de Oviedo, Lucas Fernández de Piedrahíta y fray Pedro Simón se inscriben dentro de la literatura de la Conquista, en la cual algunos sacerdotes y soldados describen vívidamente los acontecimientos de los conquistadores a su llegada a colonizar las tierras americanas. En varios casos, las crónicas de Indias no fueron escritas directamente por quienes participaron en las gestas de conquista, sino por quienes escuchaban estas historias contadas por terceras personas. Rubén D. Medina, “La crónica de Indias”, Revista Multidisciplin@, (1993): 151-163.

${ }^{33}$ Archivo General de la Nación (AGN). Sección Colonia. Fondo Visitas-Visitas Santander. Chocoa: diligencias de visita (1560). Rollo 5, f. 456r. 
escasos y no permiten determinar a ciencia cierta el número real de estos dos componentes poblacionales:

Tabla No. 1 Estadística de población a partir de la visita realizada a la encomienda de Chocoa en el año de $\mathbf{1 5 6 0}$

\begin{tabular}{|c|c|c|c|c|c|}
\hline Pueblo & Hombres & Mujeres & Menores & Muchachos & $\begin{array}{l}\text { Total de indios } \\
\text { por población }\end{array}$ \\
\hline Cuyamita & 55 & 41 & s. d. & s. d. & 96 \\
\hline Oroco & 27 & 19 & s. d. & s. d. & 46 \\
\hline Oiba & 48 & 38 & s. d. & s. d. & 86 \\
\hline Butaregua & s. d. & s. d. & s. d. & s. d. & s. d. \\
\hline Lubegara & 107 & 50 & 24 & s. d. & 181 \\
\hline Burereque & s. d. & s. d. & s. d. & s. d. & s. d. \\
\hline Chalala & 99 & 68 & s. d. & s. d. & 167 \\
\hline Sancoteo & s. d. & s. d. & s. d. & s. d. & s. d. \\
\hline Poasaque & 38 & 21 & s. d. & s. d. & 59 \\
\hline Singuanchón & s. d. & s. d. & s. d. & s. d. & s. d. \\
\hline Guanenta & 80 & 60 & s. d. & s. d. & 140 \\
\hline Corata & 134 & 66 & s. d. & s. d. & 200 \\
\hline Chocoa & s. d. & s. d. & s. d. & s. d. & s. d. \\
\hline Calvera & 41 & 17 & 3 & s. d. & 61 \\
\hline Moncora & 80 & 60 & s. d. & s. d. & 140 \\
\hline Mahavita & 19 & 12 & 2 & s. d. & 33 \\
\hline Ciribiti & 50 & 40 & s. d. & s. d. & 90 \\
\hline Lenguaruco & 48 & 20 & 24 & 2 & 94 \\
\hline Jerirá & 50 & 36 & s. d. & s. d. & 86 \\
\hline Macaregua & s. d. & s. d. & s. d. & s. d. & s. d. \\
\hline Zapamanga & 104 & 50 & s. d. & s. d. & 154 \\
\hline Choaguete & s. d. & s. d. & s. d. & s. d. & s. d. \\
\hline Sube & s. d. & s. d. & s. d. & s. d. & s. d. \\
\hline Carahota & s. d. & s. d. & s. d. & s. d. & s. d. \\
\hline Siscota & s. d. & s. d. & s. d. & s. d. & s. d. \\
\hline Total & \multicolumn{4}{|l|}{1.633} & \\
\hline
\end{tabular}

Fuente: Archivo General de la Nación (AGN). Sección Colonia. Fondo Visitas-Visitas Santander (1560 y 1572). Rollo 3, f. 260v-261r y 264; rollo 4, f. 313r-314v y 499v; rollo 5 , f. 342 , 459r, 507r y 672v; rollo 6, f. 468r; rollo 7, f. 476v y 520r; rollo 8, f. 483r; rollo 9, f. 490r y 533r; rollo 10, f. 499r y 541v; rollo 12 , f. 514 r; rollo 14 , f. $672 \mathrm{v}-673$ r; rollo 18 , f. 755 r. 
Una aproximación al poblamiento de la provincia Guane en las visitas de 1560 y 1572.

Álvaro Acevedo Tarazona - Juan Sebastián Bonilla Ayala

Es bien conocido que a la llegada de los españoles los cacicazgos prehispánicos estaban en una fase importante de transición a sociedades más complejas:

Los estadios sociales según Elman Service proponen el cacicazgo independiente como un estadio y la confederación de cacicazgos como otro, este último previo al estadio estatal. Los guanes, según la evidencia histórica y arqueológica se encontraban en proceso de transformación de cacicazgos independientes a confederación de cacicazgos $^{34}$.

Muestra de ello era el dominio de una geografía variada y extensa. En el caso de los guanes había múltiples poblados en áreas de bosque húmedo y seco, los cuales a pesar de sus distancias eran controlados por un cacique. A pesar de ser comunidades pequeñas y dispersas reconocían el gobierno de un cacique. El sistema social cacical es una forma de organización que implica la integración sociopolítica de diversas comunidades aldeanas ${ }^{35}$ y esta integración se expresa a través de poblados, formas de asentamiento humano y una centralización de tipo urbano que configura una jerarquización de los mismos poblados con diferentes niveles de urbanismo ${ }^{36}$.

Cierto es que algunos de los pueblos guanes establecieron relaciones comerciales con otros grupos como los muiscas pues sostenían una economía de orden redistributivo con pautas de comercio con otras comunidades, además de tener sistemas de almacenamiento de alimentos, viviendas diferenciadas con prácticas sociales y una red de relaciones complejas de intercambios ${ }^{37}$. No obstante, algunos indios del pueblo oroco sostenían que aquello que cultivaban en su tierra era para su sustento porque no trataban ni contrataban con nadie ${ }^{38}$, esto quiere decir que los guanes tenían en su interior grupos que habían alcanzado un determinado nivel de autosuficiencia.

\footnotetext{
${ }^{34}$ Ardila, Configuración de paisajes, 11.

${ }^{35}$ Mario Sanoja e Iraida Vargas, "La sociedad cacical del Valle de Quibor (Estado Lara, Venezuela)", en Chiefdoms in the Americas, eds. Robert Drennan and Carlos Uribe (New York: University Press of America, 1987), 201-212.

${ }^{36}$ Moreno, "Los Teres: un asentamiento", 529-530.

${ }^{37}$ Álvaro Acevedo Gutiérrez, "El proceso de hispanización del nororiente colombiano durante el siglo XVI", Reflexiones Teológicas, n. ${ }^{\circ} 6$ (2010): 237.

${ }^{38}$ Archivo General de la Nación (AGN). Sección Colonia. Fondo Visitas-Visitas Santander. Vagachica y Oroco (1572): diligencias de visita. Rollo 5, f. 341r.
} 
Ahora bien, existen pueblos para los que los documentos no arrojaron ningún dato respecto al número de sus habitantes; no obstante, si se tiene en cuenta que cada cacique tenía a su cargo grupos bastante amplios, podría llegar a pensarse que la población guane para los años de 1560 y 1572 no sobrepasaba los dos mil habitantes. Como es evidente en la información de la época, la población se hallaba bastante disminuida respecto al reporte que daban las crónicas a la llegada de los españoles a la provincia Guane, pero, ¿cuál fue la razón del descenso poblacional? La primera causa de despoblación en la provincia Guane se dio por las guerras de conquista y los excesos de los primeros conquistadores:

(...) y como al acometimiento se reparasen los indios delanteros, y los que iban en pos de ellos no pudiesen hacerlo por no estar a su arbitrio la detención, a causa de que el movimiento apresurado de los cuerpos era de alto á bajo y por sendas estrechas y limpias, dando de encuentro unos con otros, confusos y revueltos, y tal vez asidos de las manos y pies, se despeñaron los más, donde con lastimoso espectáculo quedaron hechos pedazos ${ }^{39}$.

Si bien estos eventos causaron estragos, el mayor número de muertes debe atribuirse a los visitantes más letales de las Indias: las epidemias y enfermedades que fueron trasmitidas por españoles y esclavos africanos a la población indígena y para las cuales no se había desarrollado ningún plan de inmunidad. Viruela, sarampión, influenza, peste bubónica, fiebre amarilla, cólera y posiblemente tifo fueron las enfermedades que más afectaron a los nativos $^{40}$.

A lo anterior se sumaron las muertes provocadas por la imposición de trabajos en las minas, las exageradas cargas y el traslado que se hacía de algunos indios de sus lugares naturales a otras provincias para servir en las casas de sus $\operatorname{amos}^{41}$. En los documentos existen constantes anotaciones acerca de indígenas que morían por ser llevados de tierra caliente a fría, pues el traslado de un lugar

\footnotetext{
${ }^{39}$ Fernández, Historia general, 257.

${ }^{40}$ John Michel Francis, "Población, enfermedad y cambio demográfico, 1537-1636. Demografía histórica de Tunja: una mirada crítica", en Muiscas: representaciones, cartografías y etnopolíticas de la memoria, ed. Ana María Gómez Londoño (Bogotá: Pontificia Universidad Javeriana, 2005).

${ }^{41}$ J. Michel Francis, "Población, enfermedad y cambio demográfico, 1537-1636. Demografía histórica de Tunja: una mirada crítica", Fronteras de la Historia, n. ${ }^{\circ} 7$ (2002): 61.
} 
Una aproximación al poblamiento de la provincia Guane en las visitas de 1560 y 1572.

Álvaro Acevedo Tarazona - Juan Sebastián Bonilla Ayala

a otro alteraba la acomodación biológica del natural haciéndolo más propenso a enfermedades como la influenza.

\section{Economía: entre la subsistencia, el intercambio y la tributación}

Lo primero que debe decirse en este apartado es que el régimen de encomiendas establecido por los españoles para controlar, gobernar y evangelizar a los aborígenes tenía un componente adicional: el pago de las demoras o tributos por parte de los indígenas a sus encomenderos. La encomienda no involucraba la posesión temporal o propiedad de la tierra donde se hallaban ubicados los indios, pero sí el pago de un tributo que podía estar dado en trabajo, bienes agrícolas, mantas u otros enseres que eran propiedad de la Corona y habían sido cedidos por gracias del rey a los encomenderos en reconocimiento a su labor de ganar tierras ${ }^{42}$.

Los testimonios de los caciques y de los indígenas de los diferentes pueblos sobre las demoras que debían entregar anualmente a sus encomenderos son una fuente para indagar sobre los bienes que tenían a su disposición los pueblos asentados en la provincia Guane. Los documentos encontrados sugieren que la economía de los guanes para el siglo XVI estaba basada en una serie de actividades productivas que incluían la agricultura intensiva, la pesca, la caza, la cría de hormigas, la producción artesanal y la industria extractiva: “(...) que los yndios que tienen e le son subjetos son quinze con estos que declaran e siete que andan en las mynas del Río de Oro y dos que andan huidos (...) que en su pueblo se coge maíz, batatas, yucas, auyamas, algodon e hilan e lo que hazen es para su sustento e del algodon hilan y tejen mantas"

La agricultura fue uno de los sectores más desarrollados por los guanes. Estos dedicaron la mayor parte de sus labranzas al cultivo de maíz tanto para la tributación como para su propio sustento. En sus siembras, los guanes utilizaban sistemas de terrazas y aprovechaban la variedad de pisos térmicos que se presentaban en la región. El sistema de rozas, es decir, de tala y quema, fue bastante común, mientras que las herramientas de trabajo se limitaban a palas y bueyes para cavar y arar la tierra ${ }^{44}$. Es importante destacar que la mayoría de poblados guanes se encontraban ubicados en zonas de bosque húmedo con

${ }^{42}$ Salomón Kalmanovitz, La economía de la Nueva Granada (Bogotá: Fundación Universidad de Bogotá Jorge Tadeo Lozano, 2008), 35-37.

${ }^{43}$ Archivo General de la Nación (AGN). Sección Colonia. Fondo Visitas-Visitas Santander. Lubegara: diligencias de visita (1572). Rollo 4, f. 312r.

${ }^{44}$ Morales y Cadavid, Investigaciones arqueológicas, 48. 
condiciones ambientales apropiadas para la vida, pues aún hoy son regiones que disponen de calor durante todo el año con precipitaciones. Sin embargo, sus suelos son estériles, lo que dificulta en ciertas circunstancias la producción agrícola aunque su origen volcánico puede hacerlos potencialmente fértiles ${ }^{45}$. Existe un documento que hace una acotación al respecto:

Y asi mismo tengo entendido que los sitios donde estan los dichos repartimientos y naturales dellos son muy asperos y fragosos y los mas de toda la dicha provincia de Velez y tierra larga y de muchos rios caudalosos que se pasa por ellos por cabuya por la fragosidad de la tierra y que si yo huviese de ir a visitarlos seria ympusible asi por estar los caminos zerrados por no aber comodidad ni aposentos en las mas partes para asistir hazer la visita yo y mis oficiales ${ }^{46}$.

Es decir, la zona de bosque húmedo era densa con fuertes corrientes de los ríos, lo cual dificultaba la movilidad para la realización de las visitas. De igual manera, no existía gran presencia humana en esos lugares tan agrestes. Pese a esto, los guanes se habían consolidado como el grupo social más importante en esta zona para 1540, fecha de ingreso de los conquistadores españoles al territorio guane. Sin llegar a tener la organización cacical compleja de los muiscas, sí era una sociedad agrícola y el eje de sus asentamientos lo marcaban las fuentes de agua y la calidad de los suelos ${ }^{47}$.

La documentación existente en el Archivo General de la Nación da muestra de los productos cultivados y elaborados por los indígenas guanes. La siguiente tabla elaborada a partir de la información recopilada en las visitas realizadas en 1560 y 1572 permite establecer la importancia de las mantas que eran producidas en casi todos los poblados adscritos a las encomiendas de Calvera, Mahavita, Chocoa, Lubegara, Vagachica y Oroco, seguidas del cultivo del maíz y la extracción de oro:

\footnotetext{
${ }^{45}$ Alejandro Navas Corona y Érika Marcela Angulo Moreno, Los guanes y el arte rupestrexerirense (Bucaramanga: El Libro Total, 2010), 78.

${ }^{46}$ Archivo General de la Nación (AGN). Sección Colonia. Fondo Visitas-Visitas Santander. Chocoa: diligencias de visita (1560). Rollo 9, f46r.

${ }^{47}$ Emilio Arenas, Los guane, el pueblo de la cingla (Bucaramanga: Universidad Santo Tomás, 2004).
} 
Una aproximación al poblamiento de la provincia Guane en las visitas de 1560 y 1572.

Álvaro Acevedo Tarazona - Juan Sebastián Bonilla Ayala

Tabla No. 2 Estadística de producción económica a partir de las visitas realizadas a las encomiendas de Calvera, Mahavita, Chocoa, Lubegara, Vagachica y Ocoro en los años de 1560 y 1572

\begin{tabular}{|c|c|c|c|c|c|c|}
\hline Pueblo & Oro & Gallinas & Mantas & Maíz & Alpargates & $\begin{array}{c}\text { Muchachos } \\
\text { lavadores }\end{array}$ \\
\hline Cuyamita & s. c. & & 16 & s. c. & & \\
\hline Oroco & & & 8 & 1 cosecha & s. c. & \\
\hline Oiba & & & 20 & 1 cosecha & & \\
\hline Butaregua & s. c. & & 20 & & & \\
\hline Lubegara & s. c. & & 34 & 6 cosechas & & 27 \\
\hline Burereque & & & 8 & 2 cosechas & & \\
\hline Chalala & 4 pesas & & 23 & s. c. & & \\
\hline Sancoteo & & & 20 & s. c. & & \\
\hline Poasaque & 1 tejuelo & & 20 & s. c. & & \\
\hline Singuanchón & s. c. & & 20 & s. c. & & \\
\hline Guanenta & s. c. & & 24 & s.c. & & \\
\hline Corata & s. c. & & 30 & s. c. & & \\
\hline Chocoa & & & & & & s. c. \\
\hline Calvera & & & 12 & 2 cosechas & & \\
\hline Moncora & s. c. & & 30 & s. c. & & \\
\hline Mahavita & & s. c. & 11 & 2 cosechas & & \\
\hline Ciribiti & s. c. & & 20 & s.c. & & \\
\hline Lenguaruco & & & 20 & 2 fanegas & & \\
\hline Jerirá & s. c. & & 20 & s. c. & & \\
\hline Macaregua & s. c. & & 10 & s. c. & & \\
\hline Zapamanga & s. c. & & 30 & s. c. & & \\
\hline \multicolumn{7}{|l|}{ Choaguete } \\
\hline Sube & s. c. & & & 2 cosechas & & \\
\hline Siscota & & s. c. & 10 & 2 cosechas & & 20 \\
\hline Carahota & & & 20 & 2 cosechas & & \\
\hline
\end{tabular}

Fuente: Archivo General de la Nación (AGN). Sección Colonia. Fondo Visitas-Visitas Santander (1560 y 1572). Rollo 3, f. 248; rollo 4, f. 284r y 499r; rollo 5, f. 340r, 341r, 456r, 458r, 459r, 505r y 507r; rollo 6, f. 468r; rollo 7, f. 476r y 520r; rollo 8, f. 483r; rollo 9, f. 490r, 491r y 533r; rollo 10, f. 499r y 541 r; rollo 11 , f. 505 y 507 ; rollo 12 , f. 514 r y 516 r.

El cultivo de algodón fue muy productivo para los guanes. Una vez procesado se tejían mantas, prendas de vestir y hamacas. En su mayoría, los 
pueblos entregaban como tributo a sus encomenderos mantas que hilaban y tejían, aunque se tiene evidencia de que los nativos pobladores de Lubegara, además de las mantas, tributaban hamacas ${ }^{48}$. Las mantas llegaban a medir hasta dos varas y media, algunas de ellas de color pardo y otras blancas ${ }^{49}$. Marianne Cardale ha concluido de sus trabajos sobre estas prendas que, aparte de las ya mencionadas, los guanes tejían mantas con listas delgadas de color oscuro hasta telas de fondo rojo y negro con rayas de colores y listas con motivos tejidos: "que dan a la dicha su encomendera onze mantas cada caçique que son grandes de algodón blancas y pintadas" 50 .

Además de las actividades ya mencionadas, es factible considerar que los guanes en el siglo XVI continuaron dedicándose a la caza de pequeños animales y a la pesca, tal y como se acostumbraba en tiempos anteriores a la ocupación ibérica, ya que el bosque húmedo se caracteriza por la presencia de mamíferos, aves, anfibios y reptiles. Los nativos de los pueblos de Calvera y Lubigara mencionaban que antes de que llegaran los cristianos daban a sus caciques, como parte del tributo, pescados, perdices y venados ${ }^{51}$. Otra parte del territorio guane se caracteriza por ser de bosque seco. La fauna asociada a estos bosques ha sido poco estudiada. Es notoria la presencia de mamíferos como el armadillo, aves como las águilas y varias especies de insectos únicos en este ecosistema. La cría de hormigas no se halla muy bien documentada y solo se menciona en el epítome de la Conquista. Se infiere que fue un renglón también explotado por los guanes, quienes criaban los insectos en corrales con atajos construidos de hojas anchas y los usaban para amasarlos y fabricar pan ${ }^{52}$.

${ }^{48}$ Archivo General de la Nación (AGN). Sección Colonia. Fondo Visitas-Visitas Santander. Lubegara: diligencias de visita (1572).

49 “(...) pagan de demora a su encomendero dose mantas de algodón pardo de vestir e blanco la mitad pardas e la mitad blancas e se llevan a Vélez e que las midieran e que median dos varas y media poco más o menos". Archivo General de la Nación (AGN). Sección Colonia. Fondo Visitas-Visitas Santander. Calvera y Mahavita: diligencias de visita (1572).

${ }^{50}$ Ibíd.

${ }^{51}$ Archivo General de la Nación (AGN). Sección Colonia. Fondo Visitas-Visitas Santander. Lubegara: diligencias de visita (1572).

${ }^{52}$ Marcos Jiménez de la Espada, Juan de Castellanos y su Historia del Nuevo Reino de Granada (Madrid: Tipografía de Manuel Ginés Hernández, 1889), 103-104. Con respecto a la cría de hormigas, Morales (“Tejedores indígenas en la montaña santandereana”, Boletín de Historiay Antigüedades XCIII, 831 (2005): 754) afirma que estaba establecida como una labor y "que era propiedad del cabeza de familia más cercano al lugar en virtud de adjudicaciones hechas por los caciques locales anualmente". 
Una aproximación al poblamiento de la provincia Guane en las visitas de 1560 y 1572.

Álvaro Acevedo Tarazona - Juan Sebastián Bonilla Ayala

De otro lado, los pueblos de la provincia Guane se dedicaron a la producción de algunos artículos como los alpargates y la cerámica. Los registros de tributos mencionan la producción de los primeros en los pueblos de Calvera y Mahavita donde los indios expresaban que la demora que debían darle a su encomendero cada año deseaban pagarla haciendo alpargates y mantas porque ellos hilaban y tejían en su tierra ${ }^{53}$; igualmente en el pueblo de Oroco donde había cuatro indios que hacían alpargates para su encomender ${ }^{54}$.

Si se siguen los trabajos de excavaciones realizadas en zonas correspondientes a territorio de la provincia Guane, estos muestran que sus pobladores se dedicaron a la fabricación de cerámicas empleadas como elementos de uso cotidiano o de uso ritual. Muchos de los registros arqueológicos que se tienen datan de periodos tempranos anteriores a la Conquista, pero en el siglo XVI se conoce que los indios del pueblo Lubegara eran olleros y hacían loza para venderla ${ }^{55}$.

$\mathrm{Al}$ igual que muchas de las encomiendas del Nuevo Reino, la población guane hizo parte del contingente de indígenas que participaron de la industria extractiva del oro. La explotación de bancos auríferos en el río del Oro estimuló durante el siglo XVI la exploración y poblamiento en su ribera. Vinculado a este proceso económico se dieron singulares procesos demográficos que permitieron el surgimiento de asentamientos tales como las rancherías, las cuales se constituyeron en una unidad técnica, económica y social de los lavadores de oro. Las rancherías estaban conformadas por un grupo de bohíos construidos por los mismos indios ubicados cerca de los ríos; algunas de ellas servían de vivienda a los indios y a sus cuidadores y otras se utilizaban como graneros para albergar el maíz que se recogía durante las cosechas. Las cuadrillas estaban compuestas por quince o veinte indios que eran conducidos desde sus pueblos al río del Oro para extraer el mineral que pagaban de tributo a sus encomenderos; algunos indios lograban de esta extracción ciertos excedentes que servían para la compra de artículos. En los testimonios de los caciques e indios se halla una dicotomía con respecto a las labores de extracción de oro. Por una parte, se expresa simplemente que tributaban el oro que recogían en

${ }^{53}$ Archivo General de la Nación (AGN). Sección Colonia. Fondo Visitas-Visitas Santander. Calvera y Mahavita: diligencias de visita (1572).

${ }^{54}$ Archivo General de la Nación (AGN). Sección Colonia. Fondo Visitas-Visitas Santander. Vagachica y Oroco: diligencias de visita (1572).

${ }^{55}$ Archivo General de la Nación (AGN). Sección Colonia. Fondo Visitas-Visitas Santander. Vagachica y Oroco: diligencias de visita (1572). 
las minas; de otro lado, se dice que ciertos caciques le daban a su encomendero muchachos lavadores.

A partir de algunos rastros arqueológicos y con el apoyo de lo expuesto en las crónicas y las diligencias de visita se ha podido identificar cómo y qué producían los aborígenes que habitaban la provincia Guane durante el siglo XVI, pero, ¿acaso fueron estos productos objeto de intercambio? Es posible inferir que así fue. Todas las sociedades humanas han participado en algún tipo de intercambio para asegurarse que todos sus miembros estén provistos de los recursos necesarios para subsistir. Ahora, ¿cómo eran intercambiados estos productos?, ¿dónde se llevaban a cabo los intercambios?, ¿por qué otros artículos se cambiaban dichos productos? y ¿cuál era la importancia del intercambio de estos productos?

Hasta donde se tiene noticia, los pueblos que habitaban la provincia Guane practicaron diferentes tipos de intercambio económico aunque no se puede decir que todos participaron en ellos. Los indios del pueblo de Lubegara parecen haber sido bastante activos en el comercio, pues producían en sus tierras hayo o coca con la que compraban sal y otras cosas de las que tenían necesidad, y fabricaban loza, alpargates, hamacas y mantas que luego vendían "trucadas" a los muiscas, quienes se desplazaban desde su territorio a la provincia Guane para llevar a cabo los intercambios, porque ellos "no eran mercaderes ni salían de su tierra" ${ }^{\circ 6}$.

A este respecto, es importante destacar que ha existido la tendencia a incorporar la cultura guane como un apéndice de la sociedad muisca ${ }^{57}$. Antes de la llegada de los ibéricos, el actual territorio colombiano se encontraba poblado por varias sociedades que no alcanzaron estados organizativos como la lógica europea podría entenderla. Los ibéricos tropezaron con grupos en su mayoría no estatales y con usos tecnológicos diferenciados. Fue así como en la mayoría de casos encontraron poblados, pero no ciudades; también encontraron formas de comunicación y de domesticación de plantas y animales. Es decir, el territorio colombiano estaba poblado de varios cacicazgos, entre los que se encontraban los guanes. Los cacicazgos se caracterizaron por ser unidades sociopolíticas autónomas integradas por varias aldeas o comunidades bajo el control de un cacique ${ }^{58}$, lo que demuestra que existía un control no solo político

\footnotetext{
${ }^{56}$ Archivo General de la Nación (AGN). Sección Colonia. Fondo Visitas-Visitas Santander. Lubegara: diligencias de visita (1572).

${ }^{57}$ Moreno, "Arqueología del nororiente colombiano", 139.

${ }^{58}$ Moreno, “Los Teres: un asentamiento", 527.
} 
Una aproximación al poblamiento de la provincia Guane en las visitas de 1560 y 1572.

Álvaro Acevedo Tarazona - Juan Sebastián Bonilla Ayala

y social sino también económico, cultural y religioso. Es posible encontrar afinidades culturales entre guanes y muiscas, pero por la evidencia arqueológica hasta ahora hallada no se puede afirmar que los guanes pertenecieran a la sociedad muisca.

En sus Noticias historiales de la conquista de tierra firme en las Indias Occidentales, fray Pedro Simón llama la atención sobre la existencia del famoso mercado en el área del cacique Sorocotá, ubicado en la jurisdicción de la ciudad de Vélez, donde los indios de la provincia Guane asistían semanalmente para intercambiar artículos con pueblos "comunes". Según Simón, el mercado tenía lugar desde antes de la Conquista y continuó funcionando posterior a esta. El mercado se llevaba a cabo en un lugar cercano a una piedra alrededor de la cual se ubicaba la gente. Esta piedra muy seguramente tenía una connotación de tipo religioso, motivo por el cual el cabildo de Vélez lo mudó de lugar llevándolo a una loma próxima donde se hallaba con anterioridad ${ }^{59}$.

Esto último indica que los guanes tenían, además de las visitas, otra forma de intercambio a través de su participación en mercados y que son definidos como congregaciones periódicas de individuos provenientes de distintos puntos ${ }^{60}$. En los casos que se han estudiado de productos de intercambio, la sal aparece como un objeto de primera necesidad. La sal es un elemento primordial para el metabolismo humano y, como es bien sabido, no era un producto abundante en todas las zonas del territorio del Nuevo Reino de Granada; en vista de ello, los guanes recurrían a los muiscas, uno de los pueblos fronterizos con mayor producción de $\mathrm{sal}^{61}$. El intercambio de sal no solo tenía una connotación nutricional, sino simbólica, pues era un artículo ampliamente utilizado en diversos ritos y ceremonias. De este mismo orden eran las cuentas, caracoles y oro, los cuales eran utilizados como ofrendas y en la elaboración de prendas de vestir e instrumentos musicales ${ }^{62}$.

Hasta aquí se evidencia que los pueblos que habitaban la provincia Guane organizaban dos vías de intercambio de productos: las visitas y los

${ }^{59}$ Fray Pedro, Noticias historiales, 404.

${ }^{60}$ Carl Langebaek Rueda, Mercados, poblamiento e integración étnica entre los muiscas (Bogotá: Banco de la República, 1987), 147.

${ }^{61}$ Blanca Ofelia Acuña Rodríguez, "Territorio indígena de la sal en la Sierra Nevada del Cocuy. S. XVI”, Revista Historia y Espacio, 27 (2006): (Consultada el 24 de octubre de 2016), http://bibliotecadigital.univalle.edu.co/xmlui/bitstream/handle/10893/987/003\%20ART. pdf? sequence $=1$.

${ }^{62}$ Navas y Angulo, Los giuanes, 128. 
mercados periféricos, refiriéndose al modo en que se daba cada uno ellos y aquellos productos que eran motivo del intercambio, entonces surge aquí otro interrogante: ¿cuál era la importancia que tenía para los guanes el intercambio de excedentes? Esto se explica desde el punto de vista de Kenneth Hirth ${ }^{63}$, quien define el intercambio como una forma de acceso de los diferentes grupos a productos que no se encuentran en el entorno inmediato. Hirth considera que el intercambio se halla presente en todas las sociedades porque, en primer lugar, ayuda a satisfacer las necesidades de subsistencia de familias individuales a través de formas de intercambio que sirven para mover recursos de las áreas donde se encuentran a los puntos de demanda; en segundo lugar, estabiliza la disponibilidad y minimiza las fluctuaciones en los niveles de recursos debido a la variación de las condiciones ambientales; en tercer lugar, permite que ocurra la acumulación de riqueza de una sociedad-artículos escasos, de precio elevado o exótico-; y en cuarto lugar, proporciona un mecanismo para regular las relaciones externas entre los grupos.

Retomando a Langebaek y siguiendo el concepto de intercambio esbozado por Blanca Ofelia Acuña Rodríguez en el que se entiende que el intercambio iba mucho más allá del aspecto económico, pues "los objetos utilizados en las relaciones de intercambio y redistribución funcionaron como medio de intercambio social" ${ }^{64}$, se puede distinguir, particularmente, el mercado de Sorocotá como un mercado de tipo periférico que funcionaba como centro de distribución de artículos producidos por grupos extraterritoriales y el cual se abría en sitios fronterizos; sin olvidar que Sorocotá era un territorio estratégico entre los muiscas, los guanes y los pueblos que habitaban el valle del Magdalena ${ }^{65}$.

Con base en las crónicas de Simón ${ }^{66}$, Morales y Cadavid sugieren que dentro de la provincia Guane existía un comercio interno porque "los indios

${ }^{63}$ Kenneth Hirth, "El intercambio", en Historia antigua de México: aspectos fundamentales de la tradición cultural mesoamericana, eds. Linda Manzanilla y Leonardo López Luján (México: Consejo Nacional para la Cultura y las Artes-Instituto Nacional de Antropología e HistoriaUniversidad Nacional Autónoma de México-Instituto de Investigaciones Antropológicas, 2000), 98-99.

${ }^{64}$ Acuña, "Territorio indígena de la sal", 6.

${ }^{65}$ Langebaek, Mercados, poblamiento, 150-151.

${ }^{66}$ Fray Pedro Simón fue un religioso franciscano e historiador español. En 1603 pasó a Nueva Granada; estuvo en Santo Domingo y llegó a ser provincial de la Orden Franciscana en el Nuevo Reino de Granada. A fray Pedro Simón se debe la crónica titulada Noticiashistoriales de las conquistas de Tierra Firme en las Indias Occidentales, cuya primera parte se publicó en Cuenca 
Una aproximación al poblamiento de la provincia Guane en las visitas de 1560 y 1572.

Álvaro Acevedo Tarazona - Juan Sebastián Bonilla Ayala

de Butaregua entregaban maíz y frutas a los pueblos vecinos" ${ }^{\prime 67}$. Empero, tal afirmación es una interpretación que en su momento hicieron los autores, pues esto es lo que Simón relata sobre la conquista y pacificación del pueblo de los indios de Butaregua:

Los cuales [refiriéndose a los españoles] viendo la ruina que se iba causando, hicieron que los indios amigos lenguas dieran grandes voces diciéndoles se detuvieran y vinieran a conciertos de paz y amistad (...) Sonó esto por todos los demás de la provincia, y no sin provecho, pues desde allí juzgaron muchos serle de mucho excusar contiendas con los cristianos y tratar con ellos asentadas paces, y así con esta resolución, vinieron muchos a darles, entre los cuales y de los pueblos fue Macaregua, trayendo, para mejor negociar, las armas y vestidos de Pedro Vásquez, que mataron en su pueblo, y muchas mantas y joyas de oro fino $(. . .)^{68}$.

Es claro que el escrito no habla en ningún caso de intercambios comerciales entre los indios de Butaregua y los de Macaregua, más bien relaciona los regalos que llevaron los indios de este último pueblo a los españoles para concertar la paz, lo cual deja en evidencia más que un intercambio de productos, una alianza simbólica para establecer, probablemente, relaciones sociales e incluso de exogamia con otros grupos indígenas y cuyo aspecto simbólico tendría relación con la teoría del don entendida como "toda aquella prestación de bienes y servicios sin obligación, garantía o certidumbre de retorno, realizado con la intención de crear, mantener o regenerar una relación social" 69 .

Así, entonces, es imposible inferir, por la cita de fray Pedro Simón, la existencia de un comercio interno en la provincia Guane, aunque no se

en 1626. Es tal vez, la relación más completa y valiosa de los acontecimientos acaecidos en el siglo XVI en Nueva Granada; en ella, analiza el descubrimiento, la población precolombina y el nombre dado a las nuevas tierras, haciendo gala de un escaso espíritu crítico. No obstante, ha sido la fuente de numerosos historiadores, arqueólogos y antropólogos como Jorge Morales y Gilberto Cadavid quienes han investigado acerca del comercio y la economía en la provincia Guane a partir de los escritos de fray Pedro Simón. Ver: Luis Carlos Mantilla, "Fray Pedro Simón, cronista indiano olvidado en España", Carthaginensia, vol. VIII (1992): 347-380.

${ }^{67}$ Morales y Cadavid. Investigaciones etnohistóricas y arqueológicas, 52.

${ }^{68}$ Fray Pedro, Noticias historiales, 349-350.

${ }^{69}$ Antonio Moreno Almárcegui, Ensayo sobre el don (2010), (consultado el 31 de octubre, 2016),www.unav.edu/centro/gifye/files/file/Ensayo_sobre_el_don.pdf. 
descarta del todo que ocurriera. No está de más volver sobre la particularidad que se anotaba anteriormente en relación con las visitas que se hicieron a los pueblos de la provincia de Guane, en las que algunos de estos decían que no se desplazaban a otras tierras alegando que no eran mercaderes.

Los indios de Lenguaruco producían algodón y hayo que vendían por mantas y oro que "venían a comprar a su casa"; los indios de Chocoa, por su parte, tomaban para sí parte del oro que extraían del río del Oro para pagar el tributo a su encomendero y lo usaban en la compra de sal, caracoles y cuentas ${ }^{70}$. Lo que se evidencia a partir de estos relatos es que en algunos pueblos de la provincia Guane existía un tipo de mercado que Langebaek ha denominado como visitas. Estas comportaban, fundamentalmente, una red de circulación de productos que se establecía por medio del desplazamiento de individuos a visitar comunidades amigas o potencialmente amigas $^{71}$. Es decir, se retomaría nuevamente el concepto de la teoría del don a partir de un valor simbólico más que de un intercambio económico:

El valor que se les asigna a estos elementos depende de los espacios de circulación circunscritos a límites determinados por las estructuras de relaciones sociales, de producción y de poder; por esto es preciso pensar que un mismo objeto en algunos casos funcionara como mercancía e interviniera en las relaciones económicas, y en otros como objeto no mercantil con un valor simbólico regido por las exigencias de las estructuras dominantes de la relaciones sociales, de parentesco y de poder, que intervenían directamente en la distribución de los productos a través de la reciprocidad, la redistribución y el intercambio ${ }^{72}$.

Langebaek afirma que estas visitas se daban de manera recíproca y que solo involucraban a dos comunidades en cada ocasión: una cuyo territorio servía de sede a los encuentros y otra que se movilizaba desde su territorio hasta los dominios del grupo anfitrión. En este caso no parece que las visitas se hubiesen dado siguiendo un patrón de reciprocidad; muy al contrario, los testigos indígenas eran terminantes en asegurar que eran visitados en sus casas porque ellos no dejaban sus tierras; lo que sorprende es que la razón fundamental

${ }^{70}$ Archivo General de la Nación (AGN). Sección Colonia. Fondo Visitas-Visitas Santander. Chocoa: diligencias de visita (1560).

${ }^{71}$ Carl Langebaek Rueda, Noticias de caciques muy mayores (Bogotá: Uniandes-Universidad de Antioquia, 1992), 146-147.

${ }^{72}$ Acuña, "Territorio indígena de la sal”, 6. 
Una aproximación al poblamiento de la provincia Guane en las visitas de 1560 y 1572.

Álvaro Acevedo Tarazona - Juan Sebastián Bonilla Ayala

para no salir de sus casas fuera precisamente que no tenían como oficio ser mercaderes. ¿Es factible, entonces, hablar de pueblos al interior de la provincia Guane especializados en el comercio? Por lo que se ha entendido hasta el momento podría darse una respuesta positiva; sin embargo, sería apresurado si se tiene en cuenta las pocas fuentes existentes sobre este aspecto para el siglo XVI. Por lo pronto, con esta pregunta solo se pretende abrir el camino para profundizar este aspecto con nuevas investigaciones que abarquen un espacio mucho más amplio de tiempo y que permitan dar respuesta a la misma.

\section{A modo de cierre}

Como lo expresara Ernesto Guhl, "ningún espacio antropogeográfico es imaginable sin movimiento" ${ }^{73}$, por tanto, siempre existirá una relación entre el medio físico y el hombre tal y como sucedió en el territorio guane. Los guanes se adaptaron a un territorio a la vez que modificaron su entorno geográfico de acuerdo a las necesidades más inmediatas. Esa respuesta guane frente al paisaje santandereano permitió la consolidación de un grupo étnico que, para la llegada de los españoles, se encontraba en una transición de sociedad tribal hacia la constitución de una sociedad más compleja con dominio de una geografía variada y extensa ${ }^{74}$. Los múltiples poblados guanes controlados por un cacique son muestra de una fortaleza organizacional pues a pesar de ser comunidades pequeñas y dispersas reconocían el gobierno de un solo cacique. Los poblados, los asentamientos humanos, la jerarquización de los mismos poblados y los diferentes niveles de urbanismo permiten inferir una población guane organizada.

Las condiciones geográficas del territorio ocupado por los guanes durante el siglo XVI posibilitaron la producción de una gran variedad de artículos como maíz, oro, mantas, hamacas y alpargatas tanto para el sostenimiento de la comunidad como para pagar tributos a los encomenderos y establecer intercambios comerciales con otros grupos fronterizos. Entre los guanes se originaron dos tipos de intercambio de artículos: el mercado y las visitas. Estas últimas no siguen, por lo menos en el siglo XVI, el patrón habitual de desplazamiento recíproco entre las comunidades. En el caso de los guanes no era habitual dejar sus tierras ni tenían el oficio de mercaderes. No obstante,

${ }^{73}$ Ernesto Guhl, "La geografía de las comunicaciones en Colombia”, en Colombia geográfica, (Bogotá: Instituto Geográfico Agustín Codazzi, 1990), vol. 1, 13.

${ }^{74}$ Leonardo Moreno González, "La configuración espacial, territorial y cultural de la región limítrofe de Colombia con Venezuela", C \& P, n. ${ }^{\circ} 1$ (2010): 227. 
falta una mayor investigación en relación a los mercados de los que se tiene referencia, al mismo tiempo que establecer con mayor detalle cuál era el tipo de participación de los guanes en ellos.

Los renglones de mayor producción de los guanes fueron el maíz, los artículos de algodón, el oro y la coca; los tres primeros desempeñaron un papel muy importante en el sistema de pago de demoras a la Corona, por lo que se deduce que los excedentes de estos no eran tan altos y se utilizaba lo poco que quedaba para el sustento y algunos intercambios; por su parte, de la coca obtenían mayores beneficios al no utilizarse en el pago de tributos.

Posterior a la Conquista, el sistema de intercambio de artículos entre los guanes y otros pueblos pudo verse seriamente afectado por el pago de demoras, el cual no les permitía obtener un número elevado de excedentes con que participar de muchos intercambios, sino solo producir lo que les era estrictamente necesario para su subsistencia. De los artículos que llegaban a los guanes como parte de los intercambios, el único del que se tiene certeza que fuese de primera necesidad era la sal, con lo cual el resto de objetos solo conllevaba a la acumulación de riqueza, es decir, objetos de valor significativo para sus ceremonias religiosas. Hasta el momento no se puede argumentar si estos intercambios ayudaron a mejorar las relaciones externas de los Guanes con otros grupos o si se llevaron a cabo en determinada época del año, en razón de la escasez de ciertos alimentos por condiciones ambientales.

Aunque se han realizado algunos estudios acerca de la cultura guane, sus tradiciones y territorialidad, especialmente desde la antropología forense, probablemente se está en mora de construir su producción económica y un estudio demográfico a partir de la documentación existente en el Archivo General de la Nación, pues las diligencias de visita entregan información que permiten conocer un poco más de la historia de este grupo indígena después de su contacto con los conquistadores españoles.

\section{Referencias bibliográficas}

\section{Fuentes primarias}

Archivo General de la Nación (AGN). Sección Colonia. Fondo Visitas-Visitas Santander. Calvera y Mahavita: diligencias de visita (1572).

Archivo General de la Nación (AGN). Sección Colonia. Fondo Visitas-Visitas Santander. Chocoa: diligencias de visita (1560).

Archivo General de la Nación (AGN). Sección Colonia. Fondo Visitas-Visitas Santander. Lubegara: diligencias de visita (1572). 
Una aproximación al poblamiento de la provincia Guane en las visitas de 1560 y 1572.

Álvaro Acevedo Tarazona - Juan Sebastián Bonilla Ayala

Archivo General de la Nación (AGN). Sección Colonia. Fondo Visitas-Visitas Santander. Vagachica y Oroco (1572): diligencias de visita.

Castellanos, Juan de. Elegías de varones ilustres de Indias. Bogotá: Biblioteca de la Presidencia de la República, 1955.

Fernández de Oviedo y, Gonzalo Valdés. Historia general y natural de las Indias Occidentales. Asunción: Guaranía, 1944.

Fernández de Piedrahíta, Lucas. Historia general de las conquistas del Nuevo Reino de Granada. Bogotá: Imprenta de Medardo Rivas, 1881.

Jiménez de la Espada, Marcos. Juan de Castellanos y su Historia del Nuevo Reino de Granada. Madrid: Tipografía de Manuel Ginés Hernández, 1889.

Simón, Fray Pedro. Noticias historiales de la conquista de tierra firme en las Indias Occidentales por Fr. Pedro Simón del Orden de San Francisco del Nuevo Reino de Granada. Bogotá: Casa Editorial de Medardo Rivas, 1881.

\section{Fuentes secundarias}

Acevedo, Martín David y Alejandro Navas Corona. Entre rostros y tumbas. Bucaramanga: El Libro Total, 2010.

Acevedo Gutiérrez, Álvaro. "El proceso de hispanización del nororiente colombiano durante el siglo XVI”. Reflexiones Teológicas, n. ${ }^{\circ} 6$ (2010): 233-267.

Acuña Rodríguez, Blanca Ofelia. "Territorio indígena de la sal en la Sierra Nevada del Cocuy. S. XVI”. Revista Historia y Espacio, 27 (2006), (Consultada el 24 de octubre de 2016), http://bibliotecadigital.univalle.edu.co/xmlui/bitstream/ handle/10893/987/003\%20ART.pdf? sequence=1.

Ardila, Diana. "Configuración de paisajes coloniales en el territorio guane, Santander (Colombia)". Tesis Magíster en Medio Ambiente y Desarrollo, Universidad Nacional de Colombia, 2010.

Arenas, Emilio. Los Guane, el pueblo de la cingla. Bucaramanga: Universidad Santo Tomás, 2004.

Cardale de Schrimpff, Marianne. El arte del tejido en el país guane. Bucaramanga: Banco de la República, 1993.

Carvajal, Martín. "Recuerdos arqueológicos de Santander”. Estudio, n. . . 104-107 (1941).

Cifuentes, Arturo. "Reseña de un sitio arqueológico en la Mesa de Los Santos (Santander)”. Boletín de Arqueología, n. 2 (1989): 33-40.

Contreras Delgado, Camilo. "Pensar el paisaje. Explorando un concepto geográfico". Trayectorias, vol. VII, N. ${ }^{\circ} 17$ (2005): 57-69.

Copland, Aaron. Historia de la estadística en Colombia. Bogotá: Dane, 1978.

De Mojica, Sarah. Mapas culturales para América Latina. Culturas híbridas, no simultaneidad, modernidad periférica. Bogotá: Pontificia Universidad Javeriana, 2001.

Francis, J. Michel. "Población, enfermedad y cambio demográfico, 1537-1636. Demografía histórica de Tunja: una mirada crítica”. Fronteras de la Historia, n. 7 (2002): 13-76. 
Francis, John Michel. "Población, enfermedad y cambio demográfico, 1537-1636. Demografía histórica de Tunja: una mirada crítica”. En Muiscas: representaciones, cartografías y etnopolíticas de la memoria, editado por Ana María Gómez Londoño. Bogotá: Pontificia Universidad Javeriana, 2005, 74-151.

Gamboa, Jorge. "Las instituciones indígenas de gobierno en los años posteriores a la conquista: caciques y capitanes muiscas del Nuevo Reino de Granada (15371650)". En Imperios ibéricos en comarcas americanas: estudios regionales de historia colonial brasilera y neogranadina, editado por Manolo Florentino y Carlos Eduardo Valencia Villa. Bogotá: Universidad Federal do Rio de Janeiro-Universidad del Rosario, 2008, 136-164.

Gómez Martínez, Alirio. El guane. Floridablanca: 2011. (Consultado el 18/01/2017). http://elguane.blogspot.com.co/

Guerrero Rincón, Amado Antonio y Armando Martínez Garnica. La Provincia de Guanentá.Orígenes de sus poblamientos urbanos. Bucaramanga: Ediciones UIS, 1996.

Guhl, Ernesto. "La geografía de las comunicaciones en Colombia”. En Colombia geográfica. Bogotá: Instituto Geográfico Agustín Codazzi, 1990.

Herrera, Martha. Ordenar para controlar. Ordenamiento espacial y control político en las llanuras del Caribe y en los Andes centrales neogranadinos. Siglo XVIII. Medellín: La Carreta-Universidad de los Andes-Ceso-Instituto Colombiano de Antropología e Historia, 2007.

Herrera Ángel, Martha. Poder local, población y ordenamiento territorial en la Nueva Granada-siglo XVIII. Bogotá: Archivo General de la Nación, 1996.

Hirth, Kenneth. "El intercambio". En Historia antigua de México: aspectos fundamentales de la tradición cultural mesoamericana, editado por Linda Manzanilla y Leonardo López Luján. México: Consejo Nacional para la Cultura y las Artes-Instituto Nacional de Antropología e Historia-Universidad Nacional Autónoma de México-Instituto de Investigaciones Antropológicas, 2000, 97-144.

Jiménez, Edith. "Colecciones del Museo Nacional de Arqueología: una colección de cerámica guane”. Boletín de Arqueología, vol. II, n. ${ }^{\circ}$ 5-6 (1945): 413-421.

Jiménez, G. "Cultura, territorio y migraciones. Aproximaciones teóricas”, Alteridades, vol. 11, n. $^{\circ} 22$ (2001): 5-14.

Kalmanovitz, Salomón. La economía de la Nueva Granada. Bogotá: Fundación Universidad de Bogotá Jorge Tadeo Lozano, 2008.

Langebaek Rueda, Carl. Mercados, poblamiento e integración étnica entre los Muiscas. Bogotá: Banco de la República, 1987.

Langebaek Rueda, Carl. Noticias de caciques muy mayores. Bogotá: Uniandes-Universidad de Antioquia, 1992.

Mantilla, Luis Carlos. "Fray Pedro Simón, cronista indiano olvidado en España". Carthaginensia, vol. VIII (1992): 347-380.

Martínez Garnica, Armando. La Provincia de Vélez. Orígenes de sus poblamientos urbanos. Bucaramanga: Ediciones UIS, 1997.

Medina, Rubén D. “La crónica de Indias”. Revista Multidisciplin@. (1993): 151-163. 
Una aproximación al poblamiento de la provincia Guane en las visitas de 1560 y 1572.

Álvaro Acevedo Tarazona - Juan Sebastián Bonilla Ayala

Morales, Jorge. “Tejedores indígenas en la montaña santandereana”. Boletín de Historia y Antigüedades, vol. XCIII, n. ${ }^{\circ} 831$ (2005): 745-768.

Morales, Jorge y Gilberto Cadavid. Investigaciones etnohistóricas y arqueológicas del área guane. Bogotá: Banco de la República, 1984.

Moreno, Leonardo. "Arqueología del nororiente colombiano. Los Teres: un sitio de asentamiento de las culturas prehispánicas preguane y guane”. Anuario de Historia Regional y de las Fronteras, vol. 17, n. ${ }^{\circ} 2$ (2012): 115-142.

Moreno, Leonardo. "La configuración espacial, territorial y cultural de la región limítrofe de Colombia con Venezuela”. C \& P,. n. 1 (2010): 209-237.

Moreno, Leonardo. "Los Teres: un asentamiento ordenador del territorio preguane-guane. Una aproximación al tema urbano”. Anuario de Historia Regional y de las Fronteras, vol. 18, n. ${ }^{\circ} 2$ (2013): 521-548.

Moreno Almárcegui, Antonio. Ensayo sobre el don. 2010. (Consultado 31/10/2016). www.unav.edu/centro/gifye/files/file/Ensayo_sobre_el_don.pdf

Navas Corona, Alejandro y Érika Marcela Angulo Moreno. Los guanes y el arte rupestre xerirense. Bucaramanga: El Libro Total, 2010.

Ots Capdequí, José María. España en América. Las instituciones coloniales. Bogotá: Universidad Nacional de Colombia, 1992.

Rodríguez C., José Vicente. “Características físicas de la población prehispánica de la cordillera Oriental: implicaciones etnogenéticas”. Maguare, n. ${ }^{\circ} 8$ (1992): 7-45.

Sanoja, Mario e Iraida Vargas. "La sociedad cacical del Valle de Quibor (Estado Lara, Venezuela)". En Chiefdoms in the Americas, editado por Robert Drennan and Carlos Uribe. New York: University Press of America, 1987), 201-212.

Schottelius, Justus. Arqueología de la Mesa de Los Santos. Bogotá: Educación, 1941.

Sutherland, Donald. Investigaciones preliminares sobre la prehistoria de Santander. Bucaramanga: Universidad Industrial de Santander, 1990.

Vargas, Arturo y Roberto Lleras. "Palogordo. La prehistoria de Santander en los Andes Orientales”. Boletín Museo del Oro, n. 26 (1990): 64-129. 